\title{
The Significance of Gender in Phenomenological Nursing Research
}

Bente Martinsen, Aarhus University, Aarhus, Denmark

Email: bm@nursingscience.au.dk

Pia Dreyer, Aarhus University, Aarhus, Denmark

Email: pd@nursingscience.au.dk

Anita Haahr, University College, Aarhus, Denmark

Email:anih@viauc.dk

Annelise Norlyk, Aarhus University, Aarhus, Denmark

Email: an@nursingscience.au.dk

\begin{abstract}
The aim of this paper is to discuss in the light of phenomenological philosophy, whether it can be argued that men and women have different lifeworlds and how this may legitimize the segregation of men and women in empirical nursing research. We analyzed peer-reviewed papers from 2003-2012 and scrutinized the arguments used for dividing men and women into separate groups in empirical nursing studies based on phenomenology. We identified 24 studies using gender segregation and posed the following questions: 1 . What is the investigated phenomenon as explicated by the authors? 2. What arguments do the authors use when dividing participants into gender specific groups? The analysis showed that a variety of phenomena were investigated that were all related to a specific medical condition. None appeared to be gender-specific, though the authors argued for a sole focus on either women or men. The most common argument for segregating men and women were reference to earlier studies. A few studies had references to methodology and/or philosophy as argument for a segregation of men and women. Arguments for gender segregation in empirical nursing studies based on a phenomenological approach tend to build on the conviction that experiences of health related phenomena are gendered. However, it seems to be difficult to identify conclusive arguments for this division within phenomenological philosophy. Therefore we recommend that segregation should be used with caution. Otherwise other research approaches may be more suitable.
\end{abstract}




\section{Introduction}

It has become common to accept that men and women have different worlds. This conviction gathered momentum with the publication in 1992 of 'Men are from Mars, Women are from Venus,' written by the American author and relationship counsellor John Gray (Gray, 1992). During the last 20 years, it has become widely accepted in the Western world that differences in gender are significant, and that they justify participation in gender-specific activities. From early childhood, there is a tendency to assume that even small children should be divided into genderspecific groups so they can live out their inner boy or girl in their games or in their learning. In the adult world, the assumed differences between the two sexes remain unchallenged, resulting in a growing number of gender-specific activities such as travels, courses, festivals, and TV programs specifically arranged for the one sex only. Due to men and women's assumed different values, interests, feelings and experiences, it seems natural that more and more activities are addressed to a specific gender. Also, in empirical research, men and women are commonly separated into specific gender groups. This may be well founded as there are clearly biological differences. However, the tendency seems to have entered phenomenological research and this may conflict with the philosophical beliefs of phenomenology that human experiences are not gender specific. While some researchers provide a rationale for dividing groups along gender lines, others do not appear to question or provide justification for this in their research. So, the aim of this paper is to discuss if it is relevant or possible to transfer the assumed differences between genders from our everyday life into the world of phenomenological research.

\section{Paying Attention to the Arguments Legitimising Segregation}

The notion of gender can be considered from different viewpoints. First and foremost, there are biological differences between men and women. For instance, the female body contains more fat than the male body, whereas the male body contains more muscular tissue than the female body (Nielsen \& Bojsen-Moller, 2012). Also, men are generally bigger and stronger than women. Sexual characteristics are other self-evident differences leading to a natural segregation between men and women. Thus, from a biological point of view, the human body comes in two basic variations and the differences may make it imperative that the sexes are divided into two groups in biological research. However, from a constructivist perspective, gender may also be considered an acquired performance of gendered behaviour, which is what we commonly consider as femininity and masculinity. For Butler (1990), gender is an illusion since there is no gendered self prior to its acts. Rather, gender is a socially constructed relationship, which is produced and reproduced through people's actions (Butler, 1990). Gender, therefore, is not something we 'are' but rather something we 'do' and may consist of multiple forms of masculinities and femininities. In a classical phenomenological text, Young (1980) describes different modalities of the feminine bodily existence and claims that there is no specific feminine essence that all women have by virtue of being biologically female. Femininity is, rather, a set of structures, which delimit the typical situation of being a woman in a particular society, as well as the typical way this situation is lived by the women themselves. Defined as such, it is not 
necessary that there are distinctive structures and behaviour typical of women's situation (Young, 1980). The above understandings suggest that using gender, as a sampling criterium in scientific studies requires researchers to precisely explicate their understanding of the notion of gender.

Nevertheless, this claim about gender as biology, a construction or a modality of the situation often seems to be ignored within qualitative, empirical research where men and women may be divided into gender-specific groups without any explicit reason.

In some studies, it is evident that men and women must be separated into two groups. Biological differences between the sexes imply that some issues are tied to a specific gender and, therefore, it is only possible to include one sex in studies related to these issues. A prime example is a study of the re-constructing of masculinity following radical prostatectomy for prostate cancer by Gannon, K., Guerro-Blanco, M., Patel, A., \& Abel, P.(2010). Also, some diseases are caused by a genetic disorder and therefore only exist in one gender. In a study by Dreyer, P. S., Steffensen, B. F., \& Pedersen, B. D. (2010) it was only possible to include men because Duchenne muscular dystrophy does not exist among women. Not only biological differences can substantiate arguments for solely including one sex. In some cases, biology creates the conditions for human experiences of a particular issue and it becomes the law of nature that the issue can only be investigated within one sex. For instance, Armstrong (2001) investigated fathers' experiences of pregnancy after a prior perinatal loss referring to the mothers' and fathers' different attachment to the unborn baby. Also, Hall (2004) investigated the experience of being a grandmother in a separate study. Another example of a study dealing with gender-specific experiences is a study of women's experiences of legal abortion ( van Dijk, M. G., Arellano Mendoza, L. J., Arangure Peraza, A. G., Toriz Prado, A. A., Krumholz, A., \& Yam, E. A., 2011) where it is obvious that men cannot be included. The sexes may also be segregated with reference to gender-specific characteristics making the selected gender particularly suitable as participants in the study. A study of complementary and alternative medicine only focused on women due to their relatively high use of this kind of treatment (Lindenmeyer, Jamie, Griffiths, \& Legare, 2011). Another reason to focus solely on one gender is, when a given disease is prevalent in one sex for which reason the opposite sex may be excluded. Since the majority of people with osteoporosis are women, Emmett, C. L., Redmond, N. M., Peters, T. J., Clarke, S., Shepstone, L., Lenaghan, E., \& Shaw, A. R. (2012) interviewed 30 women about their experiences with this illness. The segregation of gender in research may also be motivated by a comparison between the sexes. For example, Leegaard, M., Naden, D., \& Fagermoen, M. S. (2008) stated that women might have a lower pain threshold than men, which makes them better participants than men in a study of postoperative pain. In many studies, it is assumed that experiences are gendered. Thus, with reference to the lack of knowledge derived from one sex, researchers argue in favour of including only this sex to get insight into this particular gender's experiences. For instance a number of studies dealing with the experience of different heart diseases exclusively included women (Beal, Stuifbergen, \& Volker, 2012; Isaksson, Brulin, Eliasson, Naslund, \& Zingmark, 2012; Rolfe, Sutton, Landry, Sternberg, \& Price, 2010) referring to a one-sided focus on men's experiences. A higher or increasing mortality among one sex may also be used as an argument for including solely this gender. In a study on information and support needs of Faroese women with an acute coronary syndrome, the researchers argued that more women than men die from this disease why men were excluded Askham, J., Kuhn, L., Frederiksen, K., Davidson, P., Edward, K. L., \& Worrall-Carter, L. (2010).. The opposite situation-the selected gender tends to survive the longest-may also be used as an argument for choosing only one-sex as 
participants. Foster \& Neville (2010) describe how women over the age of 85 experience their life in New Zealand, referring to the growing group of old women in this part of the world. Eilertsen, G., Kirkevold, M., \& Bjork, I. T. (2010) presents a similar argument in a paper on recovery after stroke among elderly women in Norway.

Other studies declare to explore and compare the experiences of men and women (McCaughan, Prue, Parahoo, McIlfatrick, \& McKenna, 2011) though acknowledging that masculinity and femininity are constructed and reconstructed from context to context, which may affect the validity of the gender specific findings (McCaughan, Prue, Parahoo, McIlfatrick, \& McKenna, 2011). Galdas, P. M., Johnson, J. L., Percy, M. E., \& Ratner, P. A. (2010) segregated men and women and anticipated to find distinctive patterns of help-seeking behaviour for cardiac symptoms, but found no stereotypical masculine or feminine attitudes emerging from their data. Some of the studies do not define sex or gender as an inclusion criterion but despite that, due to other characteristics they end up with a study where only one gender is represented. For instance, Sgorbini, M., O'Brien, L., \& Jackson, D. (2009) explored the issues surrounding chronic hepatitis $\mathrm{C}$ and do not account for the gender of the participants.

In summary, several arguments are presented when men and women are segregated within empirical nursing research, using phenomenological and other approaches. The question we shall pursue in this paper is, if gender segregation within phenomenological research has been critically scrutinised.

Phenomenological philosophy does not work with a clear gender distinction making it self-evident to distinguish men from women. According to Gallagher and Zahavi (2010), the founder of the phenomenological tradition Edmund Husserl (1859-1938) created the basis for an epistemology that cuts through the dichotomy and instead focuses on the relationship between the subject (the scientist) and the object (the "thing” in focus of science). Also, within empirical phenomenological approaches, it is argued that phenomenology is an epistemology that cuts through all old ontological and epistemological dichotomies, such as subjectivism and objectivism, materialism and idealism (Dahlberg, Dahlberg, \& Nyström, 2008)

The question is if empirical researchers are creating a new dichotomy by gender segregation in phenomenological research and if there are philosophical arguments within the phenomenological tradition that would legitimise the segregation of men and women in empirical phenomenological studies. Based on the assumption that presentations of empirical phenomenological studies in peer-reviewed journals have consequences for the conduct of future research and direct implications for the legitimacy in nursing science; the aim of this paper is twofold. First, we seek to systematically scrutinise if there is a tendency to divide men and women into different groups in empirical nursing studies based on phenomenology. Second, we will discuss whether the arguments for a segregation of men and women in phenomenological research can be legitimised in light of phenomenological philosophy.

\section{Scrutinising Empirical Nursing Research}

We analysed peer-reviewed papers from 2003-2012. This was considered a sufficient time frame to ensure our ability to identify a broad variation of arguments used for gender segregation and discuss issues of importance. The search included electronic databases CINAHL, PubMed, Embase, Scopus, PsychInfo, Google Scholar as well as a chain-search. The included studies had nurse researchers listed as the author and were limited to publications in English. Besides that, 
the only pre-established criterion was that the empirical study be gender-specific and contain the term "phenomenology" in the method paragraph (Figure 1). We searched using the keywords “phenomenology”, “phenomenological approach”, “gender”, “sex”, “women”, “men”, “nursing research" and "qualitative research". One hundred and seventy-two articles were included for further reading. A flowchart containing the in- and exclusion criteria can be found in Figure 1. Twenty-four papers met the criteria and were included in the analysis where we tried to find answers to the following questions:

1. What is the investigated phenomenon as explicated by the authors?

2. What arguments do the authors use when dividing participants into gender-specific groups?

Table 1: Arguments for Segregating Men and Women into Groups

\begin{tabular}{|c|c|c|c|}
\hline Study & Design & $\begin{array}{l}\text { Investigated } \\
\text { phenomenon }\end{array}$ & Arguments for gender segregation \\
\hline $\begin{array}{l}\text { Daggett L.M. } \\
\text { (2002). “Living With } \\
\text { Loss: Middle-Aged Men } \\
\text { face Spousal } \\
\text { bereavement." }\end{array}$ & $\begin{array}{l}\text { Phenomenology with } \\
\text { reference to Patton. } 8 \\
\text { men aged } 41-54 \text { were } \\
\text { interviewed. }\end{array}$ & $\begin{array}{l}\text { The lived } \\
\text { experience of } \\
\text { loss of spouse. }\end{array}$ & $\begin{array}{l}\text { With reference to earlier studies in } \\
\text { American culture, men and women } \\
\text { experience bereavement in different } \\
\text { ways: "In general, men tend toward } \\
\text { action as a primary mode in healing their } \\
\text { grief and use relating as a secondary } \\
\text { strategy, and women are the opposite". }\end{array}$ \\
\hline $\begin{array}{l}\text { De Witt L., Ploeg J., \& } \\
\text { Black M. (2010) } \\
\text { "Living alone with } \\
\text { dementia: an } \\
\text { interpretive } \\
\text { phenomenological study } \\
\text { with older women”. }\end{array}$ & $\begin{array}{l}\text { Phenomenological } \\
\text { method as described by } \\
\text { Van Manen. } 14 \text { women } \\
\text { diagnosed with } \\
\text { Alzheimer Disease } \\
\text { were interviewed. }\end{array}$ & $\begin{array}{l}\text { The meaning of } \\
\text { living alone. }\end{array}$ & $\begin{array}{l}\text { With reference to the phenomenon } \\
\text { seeking experientially "rich data". }\end{array}$ \\
\hline $\begin{array}{l}\text { Flinck A., Åstedt-Kurki } \\
\text { P. \& Paavilainen E. } \\
\text { (2008) “Intimate } \\
\text { partner violence as } \\
\text { experienced by men”. }\end{array}$ & $\begin{array}{l}\text { Phenomenological } \\
\text { method as described by } \\
\text { Colaizzi. } 10 \text { men aged } \\
\text { 36-56 years were } \\
\text { interviewed. }\end{array}$ & $\begin{array}{l}\text { Men’s } \\
\text { experience of } \\
\text { intimate partner } \\
\text { violence in a } \\
\text { heterosexual pair } \\
\text { relationship. }\end{array}$ & $\begin{array}{l}\text { With reference to earlier studies to } \\
\text { scrutinize the experience of men to better } \\
\text { understand the phenomenon of intimate } \\
\text { partner violence in its entirety and to } \\
\text { develop suitable interventions. }\end{array}$ \\
\hline $\begin{array}{l}\text { Harrison T., } \\
\text { Stuifbergen A., Walker } \\
\text { J., Scott T., \& Choban } \\
\text { R. (2011) “The } \\
\text { Meaning of Gender } \\
\text { While Aging With } \\
\text { Paralytic Polio". }\end{array}$ & $\begin{array}{l}\text { Hermeneutic } \\
\text { phenomenological } \\
\text { method as described by } \\
\text { Cohen et al. was used. } \\
25 \text { women with polio } \\
\text { since childhood were } \\
\text { interviewed. }\end{array}$ & $\begin{array}{l}\text { The experience } \\
\text { of being } \\
\text { conscious of } \\
\text { being a woman } \\
\text { with paralytic } \\
\text { polio. }\end{array}$ & $\begin{array}{l}\text { With reference to de Beauvoir who argues } \\
\text { that when a woman ages, her physical } \\
\text { losses potentiate the loss she may } \\
\text { experience by societal withdrawal. }\end{array}$ \\
\hline $\begin{array}{l}\text { Herning M., Hansen } \\
\text { P.R., Bygbjerg B. \& } \\
\text { Lindhardt T. (2011) } \\
\text { "Women’s Experiences } \\
\text { and Behaviour at Onset } \\
\text { of Symptoms of ST } \\
\text { Segment Elevation } \\
\text { Acute Myocardial”. }\end{array}$ & $\begin{array}{l}\text { Phenomenological } \\
\text { method as described by } \\
\text { Giorgi. } 17 \text { women were } \\
\text { interviewed. }\end{array}$ & $\begin{array}{l}\text { To explore how } \\
\text { women’s } \\
\text { thoughts, } \\
\text { motivations and } \\
\text { actions } \\
\text { influenced their } \\
\text { delay in seeking } \\
\text { treatment when } \\
\text { experiencing } \\
\text { symptom. }\end{array}$ & $\begin{array}{l}\text { With reference to earlier studies women's } \\
\text { experiences in relation to acute } \\
\text { myocardial infection differs from men. } \\
\text { Furthermore there is a lack of knowledge } \\
\text { of specific female behavioural patterns in } \\
\text { connection with ST segment elevation } \\
\text { acute myocardial infarction. }\end{array}$ \\
\hline
\end{tabular}




\begin{tabular}{|c|c|c|c|}
\hline Study & Design & $\begin{array}{l}\text { Investigated } \\
\text { phenomenon }\end{array}$ & Arguments for gender segregation \\
\hline $\begin{array}{l}\text { Juuso P., Skär L., } \\
\text { Olsson M. \& Söderberg } \\
\text { S. (2011) "Living with } \\
\text { a double burden: } \\
\text { Meanings of pain for } \\
\text { women with } \\
\text { fibromyalgia". }\end{array}$ & $\begin{array}{l}\text { Phenomenological } \\
\text { hermeneutic as } \\
\text { described by Lindseth } \\
\text { \& Norberg and } \\
\text { Ricoeur. } 15 \text { women } \\
\text { with fibromyalgia were } \\
\text { interviewed. }\end{array}$ & $\begin{array}{l}\text { The meaning of } \\
\text { pain. }\end{array}$ & $\begin{array}{l}\text { With reference to earlier studies the } \\
\text { majority of people with fibromyalgia are } \\
\text { women and there is a lack of knowledge } \\
\text { about the phenomenon "meanings of } \\
\text { pain" for women with fibromyalgia. }\end{array}$ \\
\hline $\begin{array}{l}\text { Kvigne K. \& Kirkevold } \\
\text { M. (2003) “Bodily } \\
\text { strangeness: Women's } \\
\text { Living with experiences } \\
\text { of their changing and } \\
\text { unpredictable following } \\
\text { stroke”. }\end{array}$ & $\begin{array}{l}\text { Phenomenological } \\
\text { method as described by } \\
\text { Giorgi and Dahlberg. } \\
20 \text { women with first- } \\
\text { time stroke were } \\
\text { interviewed. }\end{array}$ & $\begin{array}{l}\text { The female } \\
\text { experience of the } \\
\text { body and the life } \\
\text { after a stroke. }\end{array}$ & $\begin{array}{l}\text { With reference to Merleau-Ponty's } \\
\text { (1962/1994) philosophy of the body's } \\
\text { fundamental position in creating one's } \\
\text { life world and to de Beauvoir's (1974) } \\
\text { feminist perspective stating that bodily } \\
\text { changes must be understood from a } \\
\text { gender perspective. }\end{array}$ \\
\hline $\begin{array}{l}\text { Kvigne K., Kirkevold } \\
\text { M. \& Gjengedal E. } \\
\text { (2004) "Fighting } \\
\text { back-struggling to } \\
\text { continue life and } \\
\text { preserve the self, } \\
\text { following a stroke". }\end{array}$ & $\begin{array}{l}\text { Phenomenological } \\
\text { method as described by } \\
\text { Giorgi and Dahlberg. } \\
20 \text { women with first- } \\
\text { time stroke were } \\
\text { interviewed. }\end{array}$ & $\begin{array}{l}\text { The female } \\
\text { experience of the } \\
\text { body and the life } \\
\text { after a stroke. }\end{array}$ & $\begin{array}{l}\text { With reference to Merleau-Ponty's } \\
\text { (1962/1994) philosophy of the body's } \\
\text { fundamental position in creating one's } \\
\text { life world and to be Beauvoir's (1974) } \\
\text { feminist perspective stating that bodily } \\
\text { changes must be understood from a } \\
\text { gender perspective. }\end{array}$ \\
\hline $\begin{array}{l}\text { MacAdam R. Huuva E. } \\
\text { \& Berter C. (2011) } \\
\text { "Fathers' experiences } \\
\text { after having a child: } \\
\text { sexuality becomes } \\
\text { tailored according to } \\
\text { circumstances". }\end{array}$ & $\begin{array}{l}\text { Interpretive } \\
\text { phenomenological } \\
\text { method as described by } \\
\text { Benner and Kvale. } 12 \\
\text { men were interviewed } \\
\text { six to } 13 \text { months after } \\
\text { having a child. }\end{array}$ & $\begin{array}{l}\text { Men's } \\
\text { experiences of } \\
\text { sexuality after } \\
\text { having a child. }\end{array}$ & $\begin{array}{l}\text { With reference to earlier studies } \\
\text { becoming a father can have a great impact } \\
\text { on the way in which sexuality is } \\
\text { experienced and expressed. The lack of a } \\
\text { holistic approach to this issue combined } \\
\text { with sparse qualitative research studies, } \\
\text { means that men's experiences of sexuality } \\
\text { is a relatively unexplored area. }\end{array}$ \\
\hline $\begin{array}{l}\text { Markoulakis R., } \\
\text { Fletcher P. \& Bryden P. } \\
\text { (2012) "Seeing the } \\
\text { glass half full: benefits } \\
\text { to the lived experiences } \\
\text { of female primary } \\
\text { caregivers of children } \\
\text { with autism". }\end{array}$ & $\begin{array}{l}\text { A phenomenological } \\
\text { study. } 8 \text { married female } \\
\text { primary caregivers of } \\
\text { children with autism } \\
\text { were interviewed. }\end{array}$ & $\begin{array}{l}\text { The lived } \\
\text { experiences of } \\
\text { primary } \\
\text { caregivers of } \\
\text { children with } \\
\text { autism. }\end{array}$ & $\begin{array}{l}\text { With reference to methodology is was } \\
\text { argued that to ensure homogeneity of the } \\
\text { sample, as well as to limit the effect of } \\
\text { confounding factors (i.e. gender) women } \\
\text { who identified themselves as primary } \\
\text { caregivers of children with autism were } \\
\text { chosen. Furthermore, with reference to } \\
\text { philosophy it was argued that it was } \\
\text { necessary to connect with those "who } \\
\text { have directly experienced the } \\
\text { phenomenon of interest". }\end{array}$ \\
\hline $\begin{array}{l}\text { Nordgren L., Asp M. \& } \\
\text { Fagerberg I. (2008) } \\
\text { "Support as } \\
\text { experienced by men } \\
\text { living with heart failure } \\
\text { in middle age: A } \\
\text { phenomenological } \\
\text { study". }\end{array}$ & $\begin{array}{l}\text { Reflective lifeworld } \\
\text { phenomenology as } \\
\text { described by Dahlberg. } \\
9 \text { men aged } 49-64 \text { were } \\
\text { interviewed. }\end{array}$ & $\begin{array}{l}\text { The meaning of } \\
\text { support as } \\
\text { experienced by } \\
\text { men living with } \\
\text { heart failure. }\end{array}$ & $\begin{array}{l}\text { With reference to earlier studies men’s } \\
\text { and women's life-situations differ when } \\
\text { living with heart failure. With reference } \\
\text { to philosophy it is the essential meanings } \\
\text { of a specific phenomenon, i.e. the } \\
\text { meanings that define a phenomenon as } \\
\text { itself. }\end{array}$ \\
\hline
\end{tabular}




\begin{tabular}{|c|c|c|c|}
\hline Study & Design & $\begin{array}{l}\text { Investigated } \\
\text { phenomenon }\end{array}$ & Arguments for gender segregation \\
\hline $\begin{array}{l}\text { Notter J. \& Burnard P. } \\
\text { (2006) “Preparing for } \\
\text { loop ileostomy surgery: } \\
\text { Women's accounts from } \\
\text { a qualitative study". }\end{array}$ & $\begin{array}{l}\text { Phenomenological } \\
\text { method as described by } \\
\text { Giorgi. } 50 \text { women were } \\
\text { interviewed. }\end{array}$ & $\begin{array}{l}\text { To explore and } \\
\text { describe the } \\
\text { perceptions and } \\
\text { experiences of } \\
\text { women } \\
\text { undergoing } \\
\text { restorative } \\
\text { proctocolectomy }\end{array}$ & $\begin{array}{l}\text { With reference to earlier studies it was } \\
\text { revealed that men's and women's } \\
\text { perception differ. }\end{array}$ \\
\hline $\begin{array}{l}\text { Ockander M.K. } 7 \\
\text { Timpka T. (2003) } \\
\text { "Women’s experiences } \\
\text { of long term sickness } \\
\text { absence: implications } \\
\text { for rehabilitation } \\
\text { practice and theory". }\end{array}$ & $\begin{array}{l}\text { Phenomenological } \\
\text { method as described by } \\
\text { Giorgi. } 82 \text { middle-aged } \\
\text { women were } \\
\text { interviewed. }\end{array}$ & $\begin{array}{l}\text { Woman's } \\
\text { experience of } \\
\text { long-term } \\
\text { sickness } \\
\text { absence. }\end{array}$ & $\begin{array}{l}\text { With reference to earlier studies women } \\
\text { have a higher rate of sickness absence } \\
\text { than men, according to both frequency } \\
\text { and the length of the spell. Thus, long- } \\
\text { term sickness absence is a growing } \\
\text { phenomenon and affects mostly women. }\end{array}$ \\
\hline $\begin{array}{l}\text { Olsson M., Skär L., \& } \\
\text { Söderberg S. (2010) } \\
\text { "Meanings of Feeling } \\
\text { Well for Women With } \\
\text { Multiple Sclerosis". }\end{array}$ & $\begin{array}{l}\text { Phenomenological } \\
\text { hermeneutic as } \\
\text { described by Lindseth } \\
\text { \& Norberg and } \\
\text { Ricoeur. } 15 \text { women } \\
\text { with MS were } \\
\text { interviewed. }\end{array}$ & $\begin{array}{l}\text { The meanings of } \\
\text { feeling well in a } \\
\text { life. }\end{array}$ & $\begin{array}{l}\text { With reference to earlier studies the } \\
\text { majority of people living with MS are } \\
\text { women and the chances of meeting the } \\
\text { needs of women with MS, and supporting } \\
\text { their experiences of feeling well, are } \\
\text { limited. }\end{array}$ \\
\hline $\begin{array}{l}\text { Ransom J.E., Siler B., } \\
\text { Peters R.M. \& Maurer } \\
\text { M.J., (2005) “Worry: } \\
\text { Women’s Experience of } \\
\text { HIV Testing”. }\end{array}$ & $\begin{array}{l}\text { Phenomenological } \\
\text { method as described by } \\
\text { Van Manen. } 26 \text { first- } \\
\text { time testers, non- } \\
\text { pregnant over } 18 \text { were } \\
\text { interviewed. }\end{array}$ & $\begin{array}{l}\text { The experience } \\
\text { of nonpregnant } \\
\text { women seeking } \\
\text { HIV testing. }\end{array}$ & $\begin{array}{l}\text { With reference to earlier studies research } \\
\text { on HIV testing behaviours and } \\
\text { interventions indicates a lack of } \\
\text { information about non-pregnant women's } \\
\text { testing behaviours. }\end{array}$ \\
\hline $\begin{array}{l}\text { Rutberg S., \& Öhrling } \\
\text { K. (2012) “Migraine - } \\
\text { more than a headache: } \\
\text { women's experiences of } \\
\text { living with migraine". }\end{array}$ & $\begin{array}{l}\text { Phenomenological } \\
\text { method as described by } \\
\text { Van Manen. } 10 \text { women } \\
\text { age 37-69 were } \\
\text { interviewed. }\end{array}$ & $\begin{array}{l}\text { The meaning of } \\
\text { living with } \\
\text { migraine. }\end{array}$ & $\begin{array}{l}\text { With reference to earlier studies migraine } \\
\text { is a common disorder that affects three } \\
\text { times more women than men. The } \\
\text { Swedish Migraine Association forwarded } \\
\text { the information about the study to their } \\
\text { members. } 11 \text { women and one man } \\
\text { responded. Afterwards two were excluded } \\
\text { and } 10 \text { women were included in the } \\
\text { study. }\end{array}$ \\
\hline $\begin{array}{l}\text { Schoppmann S., Schrök } \\
\text { R., Schnepp W. \& } \\
\text { Büscher A. (2007) “I } \\
\text { just showed her my } \\
\text { arms”. Bodily } \\
\text { sensations in moments } \\
\text { of alienation relates to } \\
\text { self-injurious behavior. } \\
\text { A hermeneutic } \\
\text { phenomenological } \\
\text { study”. }\end{array}$ & $\begin{array}{l}\text { Phenomenological } \\
\text { method as described by } \\
\text { Van Manen. } 5 \text { women } \\
\text { age } 18-35 \text { were } \\
\text { interviewed and } 99 \\
\text { observations were } \\
\text { performed. }\end{array}$ & $\begin{array}{l}\text { The lived } \\
\text { experience of } \\
\text { persons } \\
\text { committing self- } \\
\text { injurious } \\
\text { behaviour. }\end{array}$ & $\begin{array}{l}\text { With reference to earlier studies the } \\
\text { majority of persons showing self injuring } \\
\text { behaviours are women. Furthermore, it is } \\
\text { described as an incident that only women } \\
\text { participated in the study. It is addressed as } \\
\text { a limitation of the study that only women } \\
\text { participated, not showing the variety of } \\
\text { the phenomenon. }\end{array}$ \\
\hline
\end{tabular}




\begin{tabular}{|c|c|c|c|}
\hline Study & Design & $\begin{array}{l}\text { Investigated } \\
\text { phenomenon }\end{array}$ & Arguments for gender segregation \\
\hline $\begin{array}{l}\text { Scroggs N., Shattell M., } \\
\text { \& Cowling W. R. } \\
\text { (2010) “An Existential } \\
\text { Place of Pain: The } \\
\text { Essence of Despair in } \\
\text { Women”. }\end{array}$ & $\begin{array}{l}\text { Existential } \\
\text { phenomenological } \\
\text { approach informed by } \\
\text { Merleau-Ponty. } 14 \\
\text { women age 28-55 were } \\
\text { interviewed. }\end{array}$ & $\begin{array}{l}\text { The essence of } \\
\text { despair in } \\
\text { Women. }\end{array}$ & $\begin{array}{l}\text { This study is part of a larger study that } \\
\text { did not specifically examine women's } \\
\text { experiences of despair, through the } \\
\text { interviews provided rich data on that topic } \\
\text { regarding only women. Therefore this } \\
\text { part of the study is a secondary analysis } \\
\text { that only contains findings regarding } \\
\text { women. }\end{array}$ \\
\hline $\begin{array}{l}\text { Sundin K., Bruce E. \& } \\
\text { Barremo A. (2010) } \\
\text { “Elderly women's } \\
\text { experiences of support } \\
\text { when living with } \\
\text { congestive heart } \\
\text { failure”. }\end{array}$ & $\begin{array}{l}\text { A phenomenological } \\
\text { hermeneutic approach } \\
\text { by Lindseth \& Norberg } \\
\text { and Ricoeur } 5 \text { elderly } \\
\text { women were } \\
\text { interviewed. }\end{array}$ & $\begin{array}{l}\text { Women's } \\
\text { experience of } \\
\text { support. }\end{array}$ & $\begin{array}{l}\text { With reference to earlier studies women } \\
\text { receive less care and support than men do. }\end{array}$ \\
\hline $\begin{array}{l}\text { Tanyi R.A. (2006) } \\
\text { "Perceptions of } \\
\text { Incorporating } \\
\text { Spirituality into Their } \\
\text { Care: A } \\
\text { Phenomenological } \\
\text { Study of Female } \\
\text { Patients on } \\
\text { hermodialysis". }\end{array}$ & $\begin{array}{l}\text { Descriptive } \\
\text { Phenomenological } \\
\text { method as described by } \\
\text { Speigelberg and } \\
\text { Colaizzi. } 16 \text { women } \\
\text { age } 29-77 \text { were } \\
\text { interviewed. }\end{array}$ & $\begin{array}{l}\text { Understanding } \\
\text { of patient } \\
\text { preference for } \\
\text { spiritual care. }\end{array}$ & $\begin{array}{l}\text { In the section about purposive sampling it } \\
\text { is mentioned that only women are } \\
\text { included in the study. }\end{array}$ \\
\hline $\begin{array}{l}\text { Visekruna, S. (2010) } \\
\text { "Experiences of self- } \\
\text { management among } \\
\text { young women with type } \\
1 \text { diabetes mellitus”. }\end{array}$ & $\begin{array}{l}\text { Phenomenological } \\
\text { method as described by } \\
\text { Van Manen. } 9 \text { women } \\
\text { aged 22-30 years were } \\
\text { interviewed. }\end{array}$ & $\begin{array}{l}\text { Lived } \\
\text { experiences of } \\
\text { self- } \\
\text { management. }\end{array}$ & $\begin{array}{l}\text { With reference to earlier studies women } \\
\text { posses characteristics and experiences } \\
\text { unique and different from men. } \\
\text { Menstruation, pregnancy, puberty and } \\
\text { menopause may present challenges for } \\
\text { self-management, a prerequisite for those } \\
\text { living with Type } 1 \text { diabetes mellitus. }\end{array}$ \\
\hline $\begin{array}{l}\text { Ware J \& Raval H. } \\
\text { (2010) “A qualitative } \\
\text { investigation of fathers' } \\
\text { experiences of looking } \\
\text { after a child with a life- } \\
\text { limiting illness, in } \\
\text { process and } \\
\text { retrospect”. }\end{array}$ & $\begin{array}{l}\text { Interpretative } \\
\text { phenomenological } \\
\text { method as described by } \\
\text { Smith. In-depths } \\
\text { interviews with } 8 \\
\text { fathers. }\end{array}$ & $\begin{array}{l}\text { Experiences of } \\
\text { looking after a } \\
\text { child with a life- } \\
\text { limiting illness. }\end{array}$ & $\begin{array}{l}\text { With reference to earlier studies men } \\
\text { engage differently than women. Father's } \\
\text { show less outward distress than mothers } \\
\text { and also strive to maintain a feeling of } \\
\text { control through their work outside the } \\
\text { home. Significant gaps remain in the } \\
\text { literature regarding father's perspective. }\end{array}$ \\
\hline $\begin{array}{l}\text { Yang J.H. \& Yang B.S. } \\
\text { (2011) “Alternative } \\
\text { view of health } \\
\text { behaviour: the } \\
\text { experience of older } \\
\text { Korean women". }\end{array}$ & $\begin{array}{l}\text { Phenomenological } \\
\text { method as described by } \\
\text { Colaizzi. } 12 \text { Korean } \\
\text { women over the age of } \\
65 \text { were interviewed. }\end{array}$ & $\begin{array}{l}\text { Meanings of } \\
\text { health } \\
\text { behaviour. }\end{array}$ & $\begin{array}{l}\text { With reference to population based } \\
\text { studies older women in Korea makes up } \\
59.3 \% \text { of the total elderly population and } \\
\text { very little is known about the health } \\
\text { behaviours of this group. }\end{array}$ \\
\hline
\end{tabular}




\section{Identifying the Arguments for Segregation}

In the analysis of the 24 articles, we identified the phenomenon under investigation and searched for the arguments that were used for gender segregation. In particular, we aimed to identify if or how the authors based their arguments for gender segregation on phenomenological philosophy (table 1). As illustrated in table 1, 10 of the 24 articles were published from 2003 -2009(table 1: article 1, 3, 7, 8, 11, 12, 13, 15, 17 and 20) and 14 from 2010-2012 (table 1: article 2, 4, 5, 6, 9, 10, 14, 16, 18, 19, 21, 22, 23 and 24)"All studies were conducted in the Western world and reflected a variety of commonly used phenomenological approaches with references to Benner, Colaizzi, Dahlberg et al., Giorgi, Kvale, Lindseth \& Norberg, Merleau-Ponty, Ricoeur, Spiegelberg, and Van Manen. A majority referred to Giorgi, Lindseth and Norberg and Van Manen. Most studies argue for the phenomenological method, but do not include references to phenomenological philosophy as part of the argument.

Various phenomena were investigated. They are phrased as either "the meaning of", or as “the lived experience of”, for example “self-management”, “support”, “self-injurious behaviour”, or "body and life after a stroke" (table 1). All studies represented phenomena related to different medical conditions and to empirically derived questions. None of the phenomena investigated appear to be gender-specific. However, in all 24 studies the authors argue for a sole focus on either women or men (table 1). Eighteen studies describe female experiences and 6 masculine experiences. The only explanation of the higher number of studies on women is, according to the authors (Juuso, Skar, Olsson, \& Soderberg, 2011; Ockander \& Timpka, 2003; Olsson, Skar, \& Soderberg, 2010; Rutberg \& Ohrling, 2012; Thurang, Fagerberg, Palmstierna, \& Tops, 2010), that women experience increased rates some diseases than men; for example fibromyalgia, longterm sickness absence, alcohol dependency, Multiple Sclerosis and migraine (table 1). Though acknowledging in the background section that the phenomenon under investigation is shared by women and men, some authors state that the phenomenon contains aspects that may be genderspecific and so a design including only one sex was chosen (Kvigne, \& Kirkevold, 2003; Kvigne, Kirkevold, \& Gjengedal, 2004; Markoulakis, Fletcher, \& Bryden, 2012; Scroggs, Shattell, \& Cowling, 2010; Tanyi 2006). A more implicit assumption of gender differences is seen in the study by Visekruna , Edge, \& Keeping-Burke, (2010) based on the pre-understanding that women possess characteristics and experiences unique to their sex that may affect the lived experience of self-management of Type 1 Diabetes.

The analysis also shows references to earlier studies are the most common ground for segregating men and women. Within this argument, we found three reasons for the segregation lack of knowledge, higher prevalence in one sex or assumed difference in experience. Some authors (Juuso, Skär, Olsson, \& Soderberg, 2011; MacAdam, Huuva, \& Bertero, 2011; Olsson, Skar, \& Soderberg, 2010; Ransom, Siler, Peters, \& Maurer, 2005; Thurang, Fagerberg, Palmstierna, \& Tops, 2010; Ware \& Raval, 2007) state that the segregation aims at closing a gap in the literature and, therefore, it is necessary exclusively to focus on the under-researched sex; for example, the study by Ware and Raval (2010), who argue that there is a lack of literature regarding fathers' perspective of looking after a child with a life-limiting illness. In a similar way, Olsson et al. (2010) argues that there is limited knowledge of the experience of feeling well as a female with Multiple Sclerosis. The second common argument refers to a higher prevalence of a diagnosis among one sex in earlier studies (Juuso, Skär, Olsson, \& Soderberg, 2011; Ockander \& Timpka, 2003; Olsson, Skär, \& Soderberg, 2010; Rutberg \& Ohrling, 2012; Schoppmann, Schröck, Schnepp, \& Büscher, 2007; Thurang, Fagerberg, Palmstierna, \& Tops, 
2010; Yang \& Yang, 2011). For example in the study by Juuso et al. (2011) it is stated that the majority of people with fibromyalgia are women. The third reason for segregating men and women, that was described was the argument of an assumed difference in the lived experience between women and men (Daggett, 2002; Flinck, Astedt-Kurki, \& Paavilainen, 2008; Herning, Hansen, Bygbjerg, \& Lindhardt, 2011; MacAdam, Huuva, \& Bertero, 2011; Nordgren, Asp, \& Fagerberg, 2008; Notter \& Burnard, 2006; Sundin, Bruce, \& Barremo, 2010; Visekruna, Edge, \& Keeping-Burke, 2010; Ware \& Raval, 2007). As an example Nordgren et al. (2008) state that men and women's life situations differ when living with heart failure. Likewise MacAdam et al. (2011) argue for a difference in men and women's experience of sexuality after having a child.

Few of the included studies reference methodology and/or philosophy (de Witt, Ploeg, \& Black, 2010; Kvigne, Gjengedal, \& Kirkevold, 2003; Kvigne \& Kirkevold, 2003; Markoulakis, Fletcher, \& Bryden, 2012; Nordgren, Asp, \& Fagerberg, 2008) when arguing for a segregation of men and women. Markoulakis et al. (2012) who investigated female caregivers' lived experience of being caregiver to children with autism refer to methodology when they argue for homogeneity of the sample. In the study by de Witt et al. (2010), purposive sampling was used to achieve "information-rich participants" (p. 1700). Gender segregation is not mentioned in the inclusion criteria, but only women were included. When authors base the arguments for segregation on philosophy, they refer to "the phenomenon itself" (Nordgren, Fagerberg 2008, p. 1346). In a similar way Markoulakis et al. (2012) state that it is necessary to connect with those 'who have directly experienced the phenomenon of interest. Kvigne et al. (2004) refer to the philosophers Merleau-Ponty (1962/1994) and de Beauvoir (1974), who state that feminist phenomenological theorists have discussed how the female body's interaction with its surroundings leads to experiences and expectations that are different from male experiences. Therefore, given the body's fundamental position in creating one's lifeworld, there was a need to explore women's experiences of their bodies after a stroke (Kvigne, Gjengedal, \& Kirkevold, 2004).

\section{Study Limitations}

In the analysis, we found a majority of female experiences. But, we did not identify any references to a feminist research approach. This may be explained by our focus on nursing research. Therefore, it might have been interesting to broaden our inclusion criteria and use more keywords in the search strategy such as "feminist phenomenology." Furthermore, we did not put any emphasis in contextual analysis, i.e. in what cultural, religious and political setting the studies were performed. This could have shed light on the impact of these aspects on the perception of gender.

\section{Gender Segregation Conflicts with the Traditional Philosophical Beliefs of Phenomenology}

Our findings show that when the published research consists of one-sex studies, it seems to be natural for researchers to fill the gap with studies of the opposite sex without assessing the nature of the phenomenon or the propriety of the research method. Hence, the authors do not seem to question if it is relevant or possible to segregate men and women in a study with a 
phenomenological approach. However, in two studies, it is described as incidental that only women participated in the study and the authors consider this one-sided gender perspective a limitation of the study (de Witt, Ploeg, \& Black, 2010; Schoppmann, Schröck, Schnepp, \& Büscher, 2007). This underlines an ambiguity among nurse researchers regarding the meaning of a gender perspective on the findings in empirical phenomenological research and how empirical studies can account for gender.

Although our findings show that the authors use different arguments for the segregation of men and women, the underlying principle as seems to be that men and women have different lifeworlds. This may be true in some cases, but the question is how, when and to what extent this standpoint can be legitimised within phenomenological philosophy. Although Husserl (1954/1970) himself took up "the problem of the sexes" as a question for phenomenological investigation, the question of gender has not been given much attention in phenomenological philosophy (Oksala, 2006). Phenomenological philosophy does not argue that men and women have different lifeworlds. Everybody has his or her own individual lifeworld (Gallagher, \& Zahavi, 2010). A phenomenological consequence of different lifeworlds among men and women would be a possibility to outline both a male and a female essence. Further, phenomenological philosophy does not work with a "traditional" view of masculinity or femininity as a stable set of attributes distinguishing men from women (Young 1980; Oksala, 2006). As stressed by de Beauvoir (1974), although using the words 'women' or 'feminine,' 'she' does not refer to an archetype or a no changeless essence.

Young (1980) claims that Merleau-Ponty's (2004/1945) account of the relation of the lived body to its world applies to any human existence in a general way. At a more specific level, there is a particular style of bodily comportment, which is typically feminine or masculine. This style consists of particular modalities of the structures and conditions of the body's existence in the world. Young (1980) also stresses that some humans transcend the typical situation and definition of their gender in various degrees and respects. Accordingly, we will argue that gender segregation conflicts with the philosophical beliefs of phenomenology. From a classical phenomenological perspective, gender segregation in empirical phenomenological studies relates to the natural attitude. The natural attitude has the unquestionable axiom about gender that human beings come in two genders and that the male-female dichotomy is natural (Hawkesworth, 1997). As stated in the introduction, we do not necessarily question differences related to gender in our everyday life. It is part of our un-reflected,shared understanding that men and women may have different needs and values. Our findings show many of the phenomenological empirical studies were built on the pre-understanding. The investigated phenomenon is experienced differently among men and women (e.g.Daggett, 2002; Flinck, Astedt-Kurki, \& Paavilainen, 2008; MacAdam, Huuva, \& Bertero, 2011). This premise also formed the foundation in a study that aimed to describe differences in help-seeking behaviour between men and women with cardiac symptoms, which has been described in earlier studies (Galdas, Johnson, Percy, \& Ratner, 2010). Interestingly, they did not find any stereotypical masculine or feminine attitudes. Thus, gender segregation as a premise in empirical phenomenological research raises questions as to whether researcher openness is taken sufficiently into account. The ability to wonder and the importance of researcher openness is one of the unique characters of phenomenological research (Dahlberg, Dahlberg, \& Nyström, 2008; Giorgi, 2009). As explained by Oksala (2006), if a phenomenological researcher tries to understand what a woman is, by only investigating female experiences means already having assumed that which one seeks to explain. Besides researcher openness, variation among 
participants is also mentioned as a cornerstone in phenomenological research (Dahlberg, Dahlberg, \& Nyström, 2008). Hence, it is obvious to ask if gender segregation disregards an important variation of a phenomenon that can be experienced by men as well as women. For instance, our findings show that several studies explored the lived experience of phenomena like "loss of spouse”, “support”, “intimate partner violence”, “pain”, etc. Using differences between men and women's perceptions as a starting point for investigating these phenomena, the researchers do not take into account, or seem to ignore, both the importance of researcher openness and variation among participants.

Young (1980) acknowledges the gendered modalities, but dismisses the idea that it is possible to identify a gendered essence. Also Oksala (2006) claims that "the focus on the body is simply too limited a framework to support a philosophical understanding of gender..." (p. 233), as the philosophical meaning of gender cannot be reduced to the differences between two types of living bodies. Oksala (2006) suggests a modification of the classical phenomenology - a postphenomenological reading - that is able to deal with the notion of gender. Not to identify a concept of gender or a biological investigation of the body, but to understand the constitution of gender as a gendered experience. To achieve this, Oksala (2006) leaves out the traditional understanding of epoché and replaces it with the hermeneutical circle, "This means understanding epoché not as total, universal and complete, but as an endless, circular and always partial task” (Oksala 2006, p. 238). Starting by reading anthropological and sociological investigations and medical reports etc. while critically reflecting on one's own understanding of these texts may reveal something previously hidden about the constitution of gender. Oksala (2006) stresses that, "The aim is not to find eidetic structures of for instance female experience that characterize all women whether they come from Norway or Nigeria: it is rather to seek the structures that are constitutive of the sense of normal in our homeworld” (p.239). So, it seems that examining lived experiences from a gender perspective is only possible considering the cultural and historical context of the study and taking one's own limited experience into account.

\section{Being Aware of the Nature of the Phenomenon}

Classical phenomenological philosophy does not support the existence of gendered experiences. However, it is possible to identify some gendered modalities of being in the world that are closely connected to the concrete situation (e.g. the contemporary society). But, these modalities are not determinative of a human being with a particular gender. A post-phenomenological approach suggested by Oksala (2006), leaving out the notion of epoché, offers a comparable, but yet not conclusive understanding of gender based on existing anthropological, sociological and medical knowledge supplemented by critical reflection on one's own interpretation of the material. Such an interpretive hermeneutic approach makes it possible to investigate gender as an aspect of a given phenomenon.

When empirical phenomenological researchers use references to earlier studies as the most commonly used argument for gender segregation, they risk building their new research on studies that neglect or fail to address phenomenological philosophy's dissociation with dichotomies. Since it is difficult to identify definitive arguments for gender segregation within phenomenological philosophy, segregation should be used with caution in studies based on 
phenomenological approaches. Focusing exclusively on one gender is suitable only if the feature of the phenomenon of interest calls for it.

\section{References}

Armstrong, D. (2001). Exploring fathers' experiences of pregnancy after a prior perinatal loss. MCN the American Journal of Maternal Child Nursing, 26(3), 147-153.

Askham, J., Kuhn, L., Frederiksen, K., Davidson, P., Edward, K. L., \& Worrall-Carter, L. (2010). The information and support needs of Faroese women hospitalised with an acute coronary syndrome. Journal of Clinical Nursing, 19(9-10), 1352-1361

Beal, C. C., Stuifbergen, A., \& Volker, D. (2012). A narrative study of women's early symptom experience of ischemic stroke. The Journal of Cardiovascular Nursing, 27(3), 240252Butler, J. (1990). Gender trouble: Feminism and the subversion of identity. New York: Routledge.

Daggett, L. M. (2002). Living with loss: Middle-aged men face spousal bereavement. Qualitative Health Research, 12(5), 625-639. doi: 10.1177/104973202129120142

Dahlberg, K., Dahlberg, H., \& Nyström, M. (2008). Reflektive lifeworld research (2nd edn ed.). Lund: Studentlitteratur. (Should there be page \#s)

De Beauvoir, S. (1997/1949). The second sex. London: Penguin 1972, Vintage-books.

de Witt, L., Ploeg, J., \& Black, M. (2010). Living alone with dementia: An interpretive phenomenological study with older women. Journal of Advanced Nursing, 66(8), 16981707. doi: 10.1111/j.1365-2648.2010.05295.x

Dreyer, P. S., Steffensen, B. F., \& Pedersen, B. D. (2010). Life with home mechanical ventilation for young men with duchenne muscular dystrophy. Journal of Advanced Nursing, 66(4), 753-762.

Eilertsen, G., Kirkevold, M., \& Bjork, I. T. (2010). Recovering from a stroke: A longitudinal, qualitative study of older Norwegian women. Journal of Clinical Nursing, 19(13-14), 20042013.

Emmett, C. L., Redmond, N. M., Peters, T. J., Clarke, S., Shepstone, L., Lenaghan, E., \& Shaw, A. R. (2012). Acceptability of screening to prevent osteoporotic fractures: A qualitative study with older women. Family Practice, 29(2), 235-242

Flinck, A., Astedt-Kurki, P., \& Paavilainen, E. (2008). Intimate partner violence as experienced by men. Journal of Psychiatric and Mental Health Nursing, 15(4), 322-327. 
Foster, P., \& Neville, S. (2010). Women over the age of 85 years who live alone: A descriptive study. Nursing Praxis in New Zealand Inc., 26(1), 4-13.

Galdas, P. M., Johnson, J. L., Percy, M. E., \& Ratner, P. A. (2010). Help seeking for cardiac symptoms: Beyond the masculine-feminine binary. Social Science \& Medicine 71(1), 18-24.

Gallagher, S., \& Zahavi, D. (2010). The phenomenological mind: An introduction to philosophy of mind and cognitive science. Copenhagen: Gyldendal.

Gannon, K., Guerro-Blanco, M., Patel, A., \& Abel, P. (2010). Re-constructing masculinity following radical prostatectomy for prostate cancer. The Aging Male : The Official Journal of the International Society for the Study of the Aging Male, 13(4), 258-264.

Giorgi, A. (2009). The descriptive phenomenological method in psychology: A modified husserlian approach. Pittsburgh, PA, US: Duquesne University Press.Gray, J. (1992). Men are from Mars, women are from Venus. London: Harper Element.

Hall, E. O. (2004). A double concern: Grandmothers' experiences when a small grandchild is critically ill. Journal of Pediatric Nursing, 19(1), 61-69.

Harrison, T., Stuifbergen, A., Walker, J., Scott, T., \& Choban, R. (2011). The meaning of gender while aging with paralytic polio. Journal of Gerontological Social Work, 54(2), 138-158.

Hawkesworth, M. (1997). Confounding gender. Signs, 22(3), 649-685.

Herning, M., Hansen, P. R., Bygbjerg, B., \& Lindhardt, T. (2011). Women's experiences and behaviour at onset of symptoms of ST segment elevation acute myocardial infarction. European Journal of Cardiovascular Nursing: Journal of the Working Group on Cardiovascular Nursing of the European Society of Cardiology, 10(4), 241-247.

Husserl, E. (1970). The Crisis of European Sciences and Transcendental Phenomenology. Evanston: Northwestern University Press. Isaksson, R. M., Brulin, C., Eliasson, M., Naslund, U., \& Zingmark, K. (2012). Older women's prehospital experiences of their first myocardial infarction. The Journal of Cardiovascular Nursing, VOL(\#), doi: 10.1097/JCN.0b013e31824bcebc

Juuso, P., Skar, L., Olsson, M., \& Soderberg, S. (2011). Living with a double burden: Meanings of pain for women with fibromyalgia. International Journal of Qualitative Studies on Health and Well-Being, 6(3),

Kvigne, K., \& Kirkevold, M. (2003). Living with bodily strangeness: Women's experiences of their changing and unpredictable body following a stroke. Qualitative Health Research, 13(9), 1291-1310.

Kvigne, K., Kirkevold, M. \& Gjengedal, E. (2004). Fighting back-struggling to continue life and preserve the self after a stroke. Health Care for Women International, 25(4), 370-387 
Leegaard, M., Naden, D., \& Fagermoen, M. S. (2008). Postoperative pain and self-management: Women's experiences after cardiac surgery. Journal of Advanced Nursing, 63(5), 476-485.

Lindenmeyer, A., Jamie, K., Griffiths, F., \& Legare, F. (2011). "They're made in factories and not by witches on the allotment:" A qualitative study of midlife women in the united kingdom, exploring their approaches to complementary and alternative medicines. Health Care for Women International, 32(12), 1046-1067.

MacAdam, R., Huuva, E., \& Bertero, C. (2011). Fathers' experiences after having a child: Sexuality becomes tailored according to circumstances. Midwifery, 27(5):e149-55. doi: 10.1016/j.midw.2009.12.007 Markoulakis, R., Fletcher, P., \& Bryden, P. (2012). Seeing the glass half full: Benefits to the lived experiences of female primary caregivers of children with autism. Clinical Nurse Specialist CNS, 26(1), 48-56.

McCaughan, E., Prue, G., Parahoo, K., McIlfatrick, S., \& McKenna, H. (2011). Exploring and comparing the experience and coping behaviour of men and women with colorectal cancer at diagnosis and during surgery. Journal of Advanced Nursing, 67(7), 1591-1600.

Merleau-Ponty, M. (1994/1945). Kroppens fæenomenologi [The phenomenology of perception]. Oslo: Pax.

Merleau-Ponty, M. (2004/1945). Phenomenology of perception. New York: Routledge.Nielsen, O.F., \& Bojsen-Moller, M.J. (2012) . Anatomy and physiology. Copenhagen: Munksgaard.

Nordgren, L., Asp, M., \& Fagerberg, I. (2008). Support as experienced by men living with heart failure in middle age: A phenomenological study. International Journal of Nursing Studies, 45(9), 1344-1354.

Notter, J., \& Burnard, P. (2006). Preparing for loop ileostomy surgery: Women's accounts from a qualitative study. International Journal of Nursing Studies, 43(2), 147-159.

Ockander, M. K., \& Timpka, T. (2003). Women's experiences of long term sickness absence: Implications for rehabilitation practice and theory. Scandinavian Journal of Public Health, 31(2), 143-148.

Oksala, J. (2006). A phenomenology of gender. Continential Philosophy Review, 39(?). 229-244. doi: 10.1007/s11007-006-9025-2 (need issue \#)

Olsson, M., Skar, L., \& Soderberg, S. (2010). Meanings of feeling well for women with multiple sclerosis. Qualitative Health Research, 20(9), 1254-1261. doi: 10.1177/1049732310371103

Ransom, J. E., Siler, B., Peters, R. M., \& Maurer, M. J. (2005). Worry: Women's experience of HIV testing. Qualitative Health Research, 15(3), 382-393. 
Rolfe, D. E., Sutton, E. J., Landry, M., Sternberg, L., \& Price, J. A. (2010). Women's experiences accessing a women-centered cardiac rehabilitation program: A qualitative study. The Journal of Cardiovascular Nursing, 25(4), 332-341.

Rutberg, S., \& Ohrling, K. (2012). Migraine-more than a headache: Women's experiences of living with migraine. Disability and Rehabilitation, 34(4), 329-336.

Schoppmann, S., Schröck, R., Schnepp, W., \& Büscher, A. (2007). 'Then I just showed her my arms...' bodily sensations in moments of alienation related to self-injurious behaviour. A hermeneutic phenomenological study. Journal of Psychiatric and Mental Health Nursing, 14(6), 587-597.

Scroggs, N., Shattell, M., \& Cowling, W. R. (2010). An existential place of pain: The essence of despair in women. Issues in Mental Health Nursing, 31(7), 477-482.

Sgorbini, M., O'Brien, L., \& Jackson, D. (2009). Living with hepatitis C and treatment: The personal experiences of patients. Journal of Clinical Nursing, 18(16), 2282-2291.

Sundin, K., Bruce, E., \& Barremo, A. S. (2010). Elderly women's experiences of support when living with congestive heart failure. International Journal of Qualitative Studies on Health and Well-Being, 5(?), 10.3402/qhw.v5i2.5064. doi: 10.3402/qhw.v5i2.5064;

10.3402/qhw.v5i2.5064 volume \# needed

Tanyi, R. A., Werner, J. S., Recine, A. C., \& Sperstad, R. A. (2006). Perceptions of incorporating spirituality into their care: A phenomenological study of female patients on hemodialysis. Nephrology Nursing Journal: Journal of the American Nephrology Nurses' Association, 33(5), 532-538. Please check Journal title - appears as two titles

Thurang, A., Fagerberg, I., Palmstierna, T., \& Tops, A. B. (2010). Women's experiences of caring when in treatment for alcohol dependency. Scandinavian Journal of Caring Sciences, 24(4), 700-706.

Young, I. M.(1980). Throwing like a girl: A Phenomenology of Feminine Body Comportment Motility and Spatiality. Human studies, 3 (1), 137-156 . van Dijk, M. G., Arellano Mendoza, L. J., Arangure Peraza, A. G., Toriz Prado, A. A., Krumholz, A., \& Yam, E. A. (2011). Women's experiences with legal abortion in mexico city: A qualitative study. Studies in Family Planning, 42(3), 167-174.

Visekruna, S., Edge, D., \& Keeping-Burke, L. (2010). Experiences of self-management among young women with type 1 diabetes mellitus. Diabetes, Obesity and Metabolism, 12(Issue Supplement s!), 37-72.

Ware, J., \& Raval, H. (2007). A qualitative investigation of fathers' experiences of looking after a child with a life-limiting illness, in process and in retrospect. Clinical Child Psychology and Psychiatry, 12(4), 549-565. 
Yang, J. H., \& Yang, B. S. (2011). Alternative view of health behavior: The experience of older korean women. Qualitative Health Research, 21(3), 324-332 